\title{
QUANTITATIVE INTEGRATION OF MINERAL EXPLORATION DATA A Case Study of the Grong Mining Region of Norway
}

by

\author{
Richard Sinding-Larsen and Geir Strand
}

Areas with potential massive sulphide deposits have been identified in Norway's Grong mining region. The favourability of an area is being assessed on the basis of its similarity to different mineralization models constructed from magnetic, electromagnetic, geological and geochemical exploration data covering more than $1250 \mathrm{~km}^{2}$. Ternary surfaces generated for each of the geochemical, geological and geophysical variables are being evaluated within a model area, and relative weights are then calculated for each variable. The computed weights assign levels of importance to the component variables or characteristics of the model. Ternary maps for the different variables are then combined into one map, which expresses the degree of association between a regional cell and the model, taking into account the relative weights or importance of the respective variables that characterize the model.*

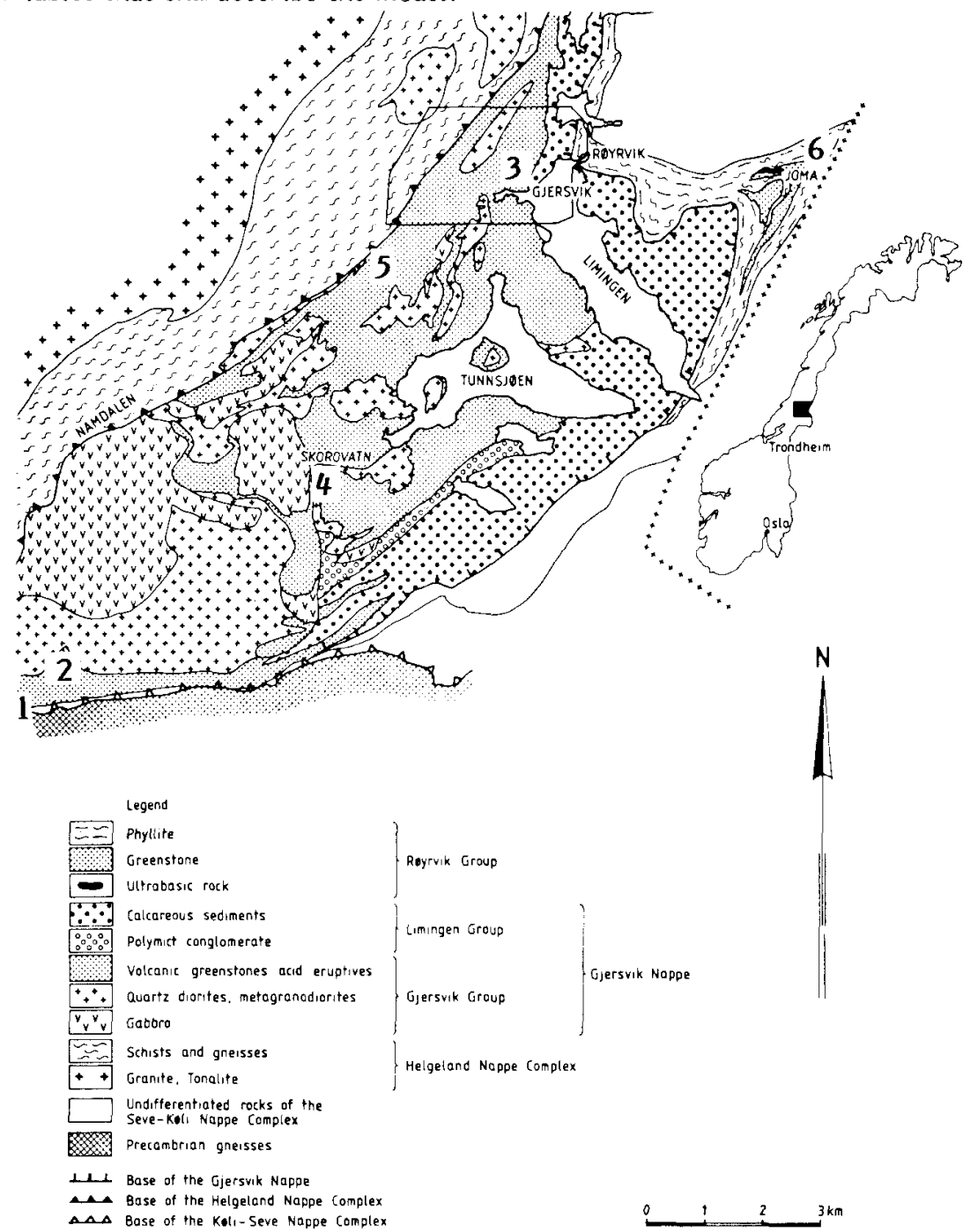

Figure 1. Simplified geological map of the Grong region, central Norway from Lutro (1979). The Gjersvik area is outlined. The numbers on the map correspond to the following mineralizations: 1 Godejord, 2 Skiftesmyr, 3 Gjersvik, 4 NESA, 5 Visletten and 6 Joma. 


\section{Iritroduction}

A rultivariate technigue has been used for identifying areas of high mineral potential within the Grong mining region in central Norway. The evaluation consists of a quantitative integration of the available geological, geophysical and geochemical information and a subsequent comparison between a 'known mineralization' (or 'model') area with other areas in the Grong district that are generally less well known.

In the past few years, increased efforts have been made in this region to develop better tools for detecting deposits that are buried beneath overburden or a rock capping. At the international level, an attempt is currently underway (Vokes, 1980) to obtain a more comprehensive understanding of the genesis of massive sulphide deposits. As the mechanisms of ore formation gradually become better understood, we should expect more effective geological, geochemical and geophysical criteria to be developed. In the meantime, there is an immediate need for more effective interpretative techniques to evaluate the subtle patterns observed in mineral exploration data. It was within this type of framework that characteristic analysis - the decision modelling procedure applied in this paper - evolved (Botbol et al., 1978).

\section{Decision Modelling}

Decision modelling by using characteristic analysis was developed in response to the recognition that the joint 'presence' or 'absence' of certain weighted combinations of particular variables could be used to 'fingerprint' sulphide mineralization in a particular situation where none of the single variables alone were sufficiently discriminatory to identify it. Such was the case for the region described here. Moreover, it was found that the logical combination of variables, a feature of the decision modelling procedure used, helped to evaluate the significance of the geochemical anomalies.

\section{Case Study}

The Grong district offered a particularly interesting case study: the greenstones contain significant sulphide deposits, much detailed work has already been carried out there in recent years, and the possibility of finding additional mineral deposits is considered to be good.

The geology of the area is shown in Figure 1 (Lutro, 1979). The major unit of the Grong district is the Gjersvik Nappe, which comprises a thick sequence of greenstones overlain by sandy and conglomeratic flysch-type rocks (Oftedahl, 1980). The greenstones, chiefly of the island arc type, are for the most part pillow lavas with associated lenses of suphides.

Two of the lenses are currently being mined. Sulphide mineralization is generally closely associated with acidic, keratophyric tuffs and lavas, agglomerates and jasper or chert containing magnetite (Kollung, 1979).

During the last ten years, more than 14000 stream sediment samples have been collected in the region, detailed geological maps have been produced, and magnetic and electromagnetic aerial surveys have been completed in an area of $1350 \mathrm{~km}^{2}$. No attempt, however, had been made to synthesize all of these data in a quantitative way in order to identify specific areas most favourable for the discovery of new deposits. To accomplish this, the Grong Mining Company initiated a decision modelling project in 1978, using characteristic analysis to integrate all available geological, geophysical and geochemical exploration data.

\section{Data Treatment}

In order to apply characteristic analysis to a given set of exploration data, it is necessary to subdivide the area of interest into regional cells and to assign to each cell a ternary value, $+1,0$, or -1 , for each variable; missing data are coded -2 . The cell value tells us whether a variable, judged to be an attribute of the mineralization, is present $(+1)$, 'don't know' if present $(0)$, or absent $(-1)$ at a cell location. A mineralization model is defined as a weighted linear combination of a set of attributes. The weights for a specified model are determined on the basis of the mutual correlation among EPISODES, Vol. 1981, No. 1.

the variables observed within an area, which is defined by a particular chosen set of cells containing mineralization of the specified model.

The exploration data in this study covering the Gjersvik Nappe region were coded into 5000 regional cells measuring $500 \mathrm{~m}$ on a side. The geological map data were transformed into ternary form by coding the presence or absence of the different lithologies. For the geochemical variables, $\mathrm{Cu}, \mathrm{Pb}$, $\mathrm{Zn}, \mathrm{Ni}, \mathrm{V}, \mathrm{Mn}, \mathrm{Fe}, \mathrm{Co}, \mathrm{Ag}, \mathrm{Cd}$ and $\mathrm{Mo}$, the presence or absence of anomalies was evaluated by comparison of the data to thresholds. Above threshold, cells contained samples deviating significantly from the general background within a cell and the surrounding cells.

For the geophysical data, which consisted of magnetic and electromagnetic recordings, a different coding procedure was used. The original contour maps were considered as geophysical surfaces and analysed in terms of morphological questions of the following type: within a given cell is there, for example, a regional magnetic feature like a plateau, slope, mountain range, valley, shelf, or a local magnetic feature like a peak, depression or a ridge? Local changes in the regional structures and the position of these local perturbations in relation to the regional structures were also coded.

TABLE 1

Variables used to describe exploration data within Grong region

Variables Description

Magnetic Variables

MA 1 Regional magnetic gradient

MA 2 Local decrease in regional magnetic gra-

MA 3

MA 4

MA 5 dient

Local increase in regional magnetic gradient Local magnetic peak

Joint presence of $\mathrm{MAl}$ as well as either MA3 and/or MA4

Electromagnetic Variables

IM 6 Imaginary anomaly

IM 7 Local imaginary anomaly or anomaly peak on a regional anomaly zone

LE 8 Estimate of conductivity calculated

RE 9 Absence of either a positive or negative real anomaly in the cell and adjacent cells

RE $10 \quad$ Negative real anomaly in cell and adjacent cell

RE 11 Positive real anomaly in cell and adjacent cell

Geological Variables

FIN A tuffitic-sedimentary sequence consisting of green schist, calcareous schist phyllites, thin lavas, keratophyres, quartzites and a persistent limestone

KER Quartz keratophyre

GRO Several greenstone units. The older greenstone is characterized by a marked banded structure. The middle greenstone is typically fine grained, dark green and massive to moderately schistose, and magnetite and pyrite are common. The younger greenstone is somewhat lighter and coarser grained than the middle greenstone, and has little or no magnetite and pyrite.

Geochemical Variables

$\mathrm{Cu}, \mathrm{Pb}, \mathrm{Zn}_{\mathrm{n}} \quad \mathrm{A}$ cell is anomalous for one of the elements if its concentration in one of the cell samples deviates significantly from the geochemical background defined as the average value of the concentration of the lowest samples in the eight adjacent cells.

$\mathrm{Cu} / \mathrm{Ni}, \mathrm{Pb} / \mathrm{Ni}$, $\mathrm{Zn} / \mathrm{Ni}, \mathrm{Cu} / \mathrm{Zn}$, $\mathrm{Pb} / \mathrm{Zn}_{\mathrm{n}} \mathrm{Zn} / \mathrm{Mn}$, $\mathrm{Zn} / \mathrm{V}$
Ratios between the deviation from background for selected elements 
In the pilot study, more than 150 variables were initially coded for each cell and subsequently evaluated in terms of their relevance for the presence of sulphide mineralization. Only 27 of these 11 geophysical, 3 geological and 13 geochemical variables (Table 1) were used in the final decision modelling project. Most of the variables rejected proved to be either inconsistent throughout the area or apparently unrelated to the existing mineralizations.

Compound variable construction is a feature of the decision modelling procedure that provides the capability of logically combining any of the variables. It proved particularly useful in this study in eliminating geochemical anomalies not related to sulphide mineralization. Some of the $\mathrm{Cu}, \mathrm{Pb}$ and $\mathrm{Zn}$ anomalies defined in Table 1 can be caused by local changes in Eh, $\mathrm{pH}$ or coprecipitation by $\mathrm{Fe}$ and $\mathrm{Mn}$ (Sinding-Larsen, 1977). The logical combination, a new variable, of the trace element ratio and the trace element in the numerator are given the value +1 for each cell where both of them are +1 .

In addition to the 27 variables in Table 1 , the following 7 new logical variables were constructed: $(\mathrm{Cu} / \mathrm{Ni}) \times \mathrm{Cu},(\mathrm{Cu} / \mathrm{Zn}) \times$ $\mathrm{Cu},(\mathrm{Pb} / \mathrm{Ni}) \times \mathrm{Pb},(\mathrm{Pb} / \mathrm{Zn}) \times \mathrm{Pb},(\mathrm{Zn} / \mathrm{Ni}) \times \mathrm{Zn},(\mathrm{Zn} / \mathrm{Mn}) \times \mathrm{Zn}$ and $(Z n / V) \times Z n$ where $x$ signifies the logical operator AND.

An example of this is shown in Figure 2 for two variables $\mathrm{Cu} / \mathrm{Ni}$ and the $\mathrm{Cu}$. It can be seen that the logical variable $(\mathrm{Cu} / \mathrm{Ni}) \times \mathrm{Cu}$ is only +1 when copper is significantly enriched compared to $\mathrm{Ni}$ as well as to the background values in the adjacent cells.

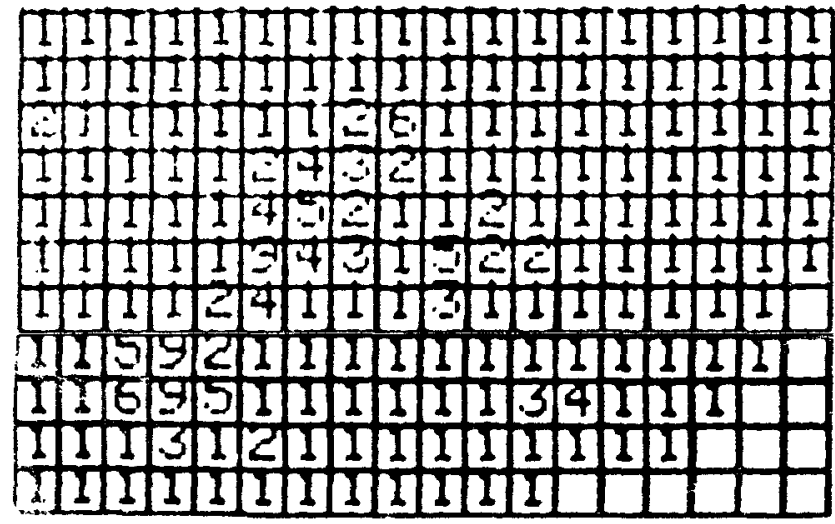

Figure 2. Vector magnitudes from 1 to 9 expressing favourability for the presence of a model in region cells. The blank cells represent Lake Limingen shown in Figure 1.

\section{Mineralization Models}

Characteristic analysis involves the comparison between the set of attributes of a regional cell and the set of attributes of the model cells. As already mentioned, a model is defined by a set of attribute weights, which are calculated for a particular control area defined by a chosen group of regional cells. Three mineralized areas within the Grong district were selected as models. Each of the three models was characterized with respect to the same variables. Based on the model cells, the characteristic vectors for each model were calculated using the method of principal components. The vector of weights consists of the loadings of the first principal component of the 'correlation' matrix of the selected attributes in the model cells. This matrix is formed by multiplying the ternary coded data matrix with its transpose for the model under consideration. The characteristic weights for the three mineralization models, M1, M2 and M3 are shown in Table 2.

\section{Generalized Models}

In order to obtain more stable models, the mineralized models were generalized by the following procedure. After an initial analysis, the regional cells with the highest scores were selected for possible inclusion in the generalized model. EPISODES, Vol. 1981, No. 1.

For each pair of variables, we then calculated the probability of obtaining by chance the observed number of matches given the number of cells in the expanded model and the frequency of occurrence of each variable. Those of the selected cells, which were similar to the mineralized cells for given pairs of variables and had a number of matches far beyond what would be expected by chance, were added to the mineralized cells and constituted the new generalized model.

The characteristic weights of the three generalized models G1, G2, and G3 differentiate the importance of the variables more effectively than the mineralized model weights and were the ones used in computing the mineral potential of the region. It should be emphasized, however, that interactive iterative procedures in the decision modelling program allow re-selection of attributes and/or cells prior to the final regional computations. This re-selection is intended for 'fine-tuning' of the models.

\section{TABLE 2}

Characteristic Weights of Variables in the Mineralized Models, the Generalized Models, and Lithogeochemical Models for the following areas: 1) Godejord, 2) Skiftesmyr, 3) Gjersvik in the Grong district, Norway. Zero or negative values have been omitted.

Models Godejord Models Skif tesmyr Models

Gjersvik Models

\begin{tabular}{|c|c|c|c|}
\hline & M1G1 LI & $\mathrm{M} 2 \mathrm{G} 2 \mathrm{~L} 2$ & $\mathrm{M} 3 \mathrm{G} 3 \mathrm{~L} 3$ \\
\hline Number of cells & 2118 & 2106 & $\begin{array}{ll}6 & 19\end{array}$ \\
\hline
\end{tabular}

MA 1

MA 2

MA 3

MA 4

MA 5

IM 6

IM 7

LE 8

RE 9

RE 10

RE 11

KER

GRO

FIN

$\mathrm{Ni}$

$\mathrm{Cd}$

Ag

$\mathrm{Cu} / \mathrm{Ni} \times \mathrm{Cu}$

$\mathrm{Cu} / \mathrm{Zn} \times \mathrm{Cu}$

$\mathrm{Pb} / \mathrm{Ni} \times \mathrm{Pb}$

$\mathrm{Pb} / \mathrm{Zn} \times \mathrm{Pb}$

$\mathrm{Zn} / \mathrm{Ni} \times \mathrm{Zn}$

$\mathrm{Zn} / \mathrm{Mn} \times \mathrm{Zn}$

$\mathrm{Zn} / \mathrm{V} \times \mathrm{Zn}$

Several other model variants were tested with emphasis on logical combinations of variables and other criteria for included cells. Some of these modelling examples were defined on the basis of the lithogeochemical attributes of the three mineralized areas and named L1, L2 and L 3 in Table 2. Even when these models are based on different numbers of cells, their characteristic weights are remarkably similar to the $M$ and $G$ models.

\section{Assessment of Potential for Sulphide Mineralization}

At present, weighted models have been constructed and established as criteria for comparing each regional cell of the subject area. All that remains is the computation of the degree of association between each cell and the model. This is accomplished by multiplying the binary vector that represents the variables of each regional cell with the vector of weights representing the equivalent variables in the model. The resultant vector magnitude will thus be a function of the computed contribution of each variable.

An arbitrary ninefold subdivision of this vector was chosen on the basis of the histogram of the magnitudes, and a number 


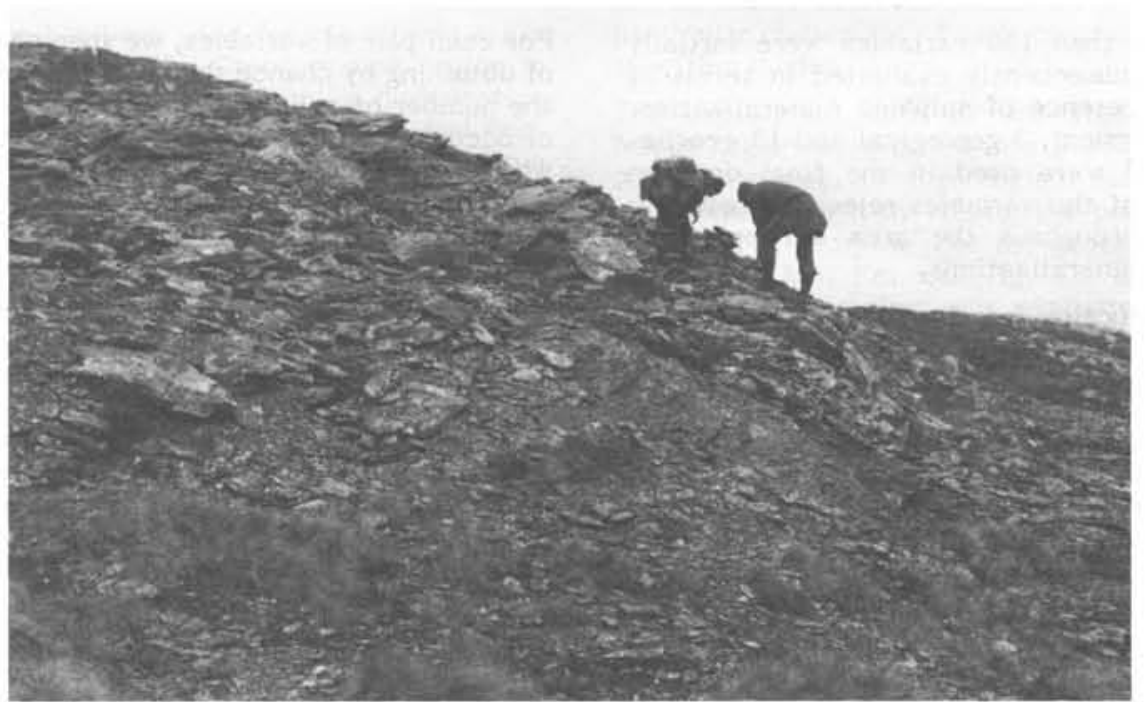

Figure 3. Authors investigate a rusty felsic agglomerate near the volcanic feeder zone.

from 1 to 9 allocated to the regional cells. More than 4900 of the regional cells have scores of 5 or less. For the different models, it can be seen (Table 3) that there is marked clustering of high and low scores, with a break between 7 and 8, which corresponds to cells with a high and low sulphide mineral potential respectively, according to the modelling procedure. One of the areas with high scores (9) for model 2 (see Table 3) is shown in Figure 2 and is currently being investigated by the Grong Mining Company. The preliminary results, which indicate the presence of a volcanic feeder zone (Fig. 3), are very promising and will be followed up by drilling.

TABLE 3

Number of Regional Cells with high scores for the Mineralized, Generalized and Lithogeochemical Models from 1) Godejord, 2) Skiftesmyr, 3) Gjersvik.

Regional

Cell Score M1GIL1 M2G2L2 M3G3L3

\begin{tabular}{cccccccccc}
\hline 9 & 2 & 2 & 6 & 2 & 6 & 7 & 4 & 9 & 12 \\
8 & 1 & 4 & 0 & 0 & 2 & 2 & 6 & 8 & 3 \\
7 & 9 & 4 & 5 & 2 & 2 & 0 & 2 & 7 & 15 \\
6 & 6 & 13 & 10 & 4 & 6 & 3 & 7 & 24 & 12 \\
5 & 9 & 19 & 9 & 16 & 15 & 9 & 5 & 16 & 30
\end{tabular}

\section{Conclusion}

Decision modelling using characteristic analysis allows the combination and use of any multidisciplinary data expressed in a binary or ternary form to characterize a model and to evaluate the similarity between a region and the model according to computed weights for each model variable. The selected model may be part of the region of interest, or from other parts of the world, or it can be a non-existing hypothetical model defined by the geologist. Used by an experienced interpreter, this method should be a valuable tool in resource appraisals and/or target selection, for the interactive nature of the analytic process enhances the interpreter's capability to appraise.

\section{Acknowledgements}

The authors are grateful to Mr. A. Haugen, Grong Gruber $\mathrm{A} / \mathrm{S}$, and to his company for their support during the project.

\section{References}

Botbol, J.M., Sinding-Larsen, R., McCammon, R.B., and Gott, G.B., 1978, A regionalized multivariate approach to target selection in geochemical exploration: Economic Geology, v.73, no. 4, p.534-546.

EPISODES, Vol. 1981, No. 1.
Kollung, S., 1979, Stratigraphy and major structures of the Grong district, Nord-Trondelag: Nor. Geol. Unders. Bull. 52, no. 354, p.1-51.

Lutro, O., 1979, The geology of the Gjersvik area, NordTrondelag, central Norway: Nor. Geol. Unders. Bull. 52, No. 354, p.53-100.

Oftedahl, C., 1980, Geology of Norway: Nor. Geol. Unders. Bull.54, no. 356, p.3-114.

Olesen, O., 1980, Follow up work in areas with mineralization potential in the Grong region: Unpublished Thesis, Norwegian Institute of Technology, $124 \mathrm{p}$.

Sinding-Larsen, R., 1977, Comments on the statistical treatment of geochemical exploration data: Sciences de la Terre. Informatique Géologique, no. 9, p.73-90.

Vokes, F.M., 1980., Project No. 60: Correlation of Caledonian stratabound sulphides: Geological Correlation, no. 8, p.102-104.

\section{ABOUT THE AUTHORS:}

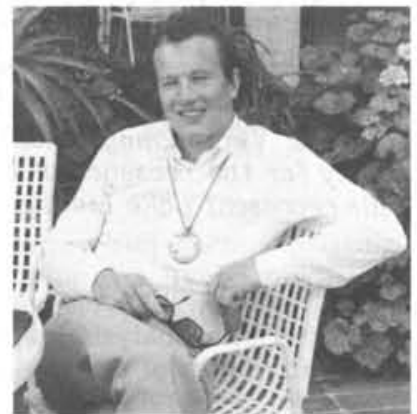

Dr. Richard Sinding-Larsen is with the Norwegian Institute of Technology in Trondheim. He is currently Chairman of the IUGS Commission on Storage, Automatic Processing and Retrieval of Geological Data (COGEODATA), and a member of the IGCP Scientific Committee.

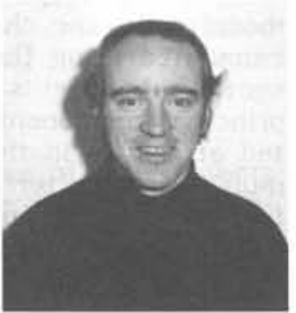

Geir S. Strand is staff geologist in the economic geology section of the Geological Survey of Norway in Trondheim. Educated in the Norwegian Institute of Technology, he currently specializes in the application of computer methods to the assessment of mineral resources. 